\title{
Economic and environmental benefits in the production of photovoltaic solar electric energy using a solar tracking system in the municipality of Acacias - Meta (Colombia)
}

\author{
Ángel Alejandro Rodríguez Aya ${ }^{\# 1}$, John Alejandro Figueredo Luna ${ }^{\# 2}$, Juan Alejandro Chica García ${ }^{* 3}$ \\ " Universidad Nacional Abierta y a Distancia, Escuela de Ciencias Básicas, Tecnología e Ingeniería \\ Km 1 vía Villavicencio, Acacias, Meta, Colombia \\ 1 angel.rodriguez@unad.edu.co \\ 2john.figueredo@unad.edu.co \\ * Corporación Universitaria Autónoma de Nariño, Investigaciones \\ Km 1 vía Acacias, Villavicencio, Meta, Colombia \\ ${ }^{3}$ juan.chica@aunarvillavicencio.edu.co
}

\begin{abstract}
The following article presents the results of the research entitled Design and implementation of a fixed and mobile photovoltaic system to capture the solar power, determining the cost-benefit relation for the Acacias CEAD; research based on determining the solar energy potential that affects the National Open University and Distance - UNAD, located in the municipality of Acacia. In addition, this article will determine the solar radiation in the area, solar power per $\mathrm{m}^{2}$ and cost-benefit ratio of the capture of photovoltaic solar electric energy between a fixed panel system and a solar tracking system. This investigation establishes that an additional production of $61.09 \%$ of electric energy is captured from solar panels with tracking compared to fixed solar panels.
\end{abstract}

Keyword - Photovoltaic solar energy, solar tracking system, Renewable energies, solar power, cost benefit.

\section{INTRODUCTION}

Renewable energies such as solar, wind, hydroelectric and biomass have aroused great interest in the world as a possible solution to the production of non-renewable energies derived from coal, oil and gas [1], which through the history have had a volatile market, with their costs depending on the internal policies of each country. In addition, there is a need to reduce $\mathrm{CO}_{2}$ emissions in the atmosphere in order to mitigate global warming, as a reference to the European Union which possess close to $40 \%$ of the world's patents related to renewable energy and are adopting a transition of energy production through clean energy [2].

Moreover, at the Paris climate conference (COP21), held in December 2015, 195 countries signed the first binding global climate agreement. Their main commitment is directed towards the reduction of greenhouse gas emissions and greenhouse effects, with which it is intended to keep below $2{ }^{\circ} \mathrm{C}$ the increase in global average temperature [3]. Colombia is currently one of the countries that has ratified the Paris agreement and has committed to reducing greenhouse gas emissions by $20 \%$ by the year 2030 . As a first step, it has begun with the tax levy on a gallon of ACPM (\$ 152 pesos), gasoline (\$ 135 pesos) and liquefied petroleum gas (\$ 95 pesos) and soon to kerosene, jet fuel and fuel oil. This tax will have an increase of $1 \%$ per year until the year 2050 [4].

The development of new techniques and technologies have reduced the cost of the implementation of photovoltaic solar energy [5]. One of these phenomena is the production of solar panel manufacturing in China. In addition to the decrease in the cost of polysilicon, the main component in the manufacture of solar panels, there is also an important improvement in the implementation of techniques that improve the efficiency of the photovoltaic cells. This has managed to reduce the cost of solar panels, reducing from an average cost of \$ 1.31 dollars per watt in the year 2011 to an average cost of $\$ 0.50$ dollars per watt for the year 2014. There is to be an estimated reduction by the end of 2017 of the cost of solar panels by $40 \%$ [6]. 


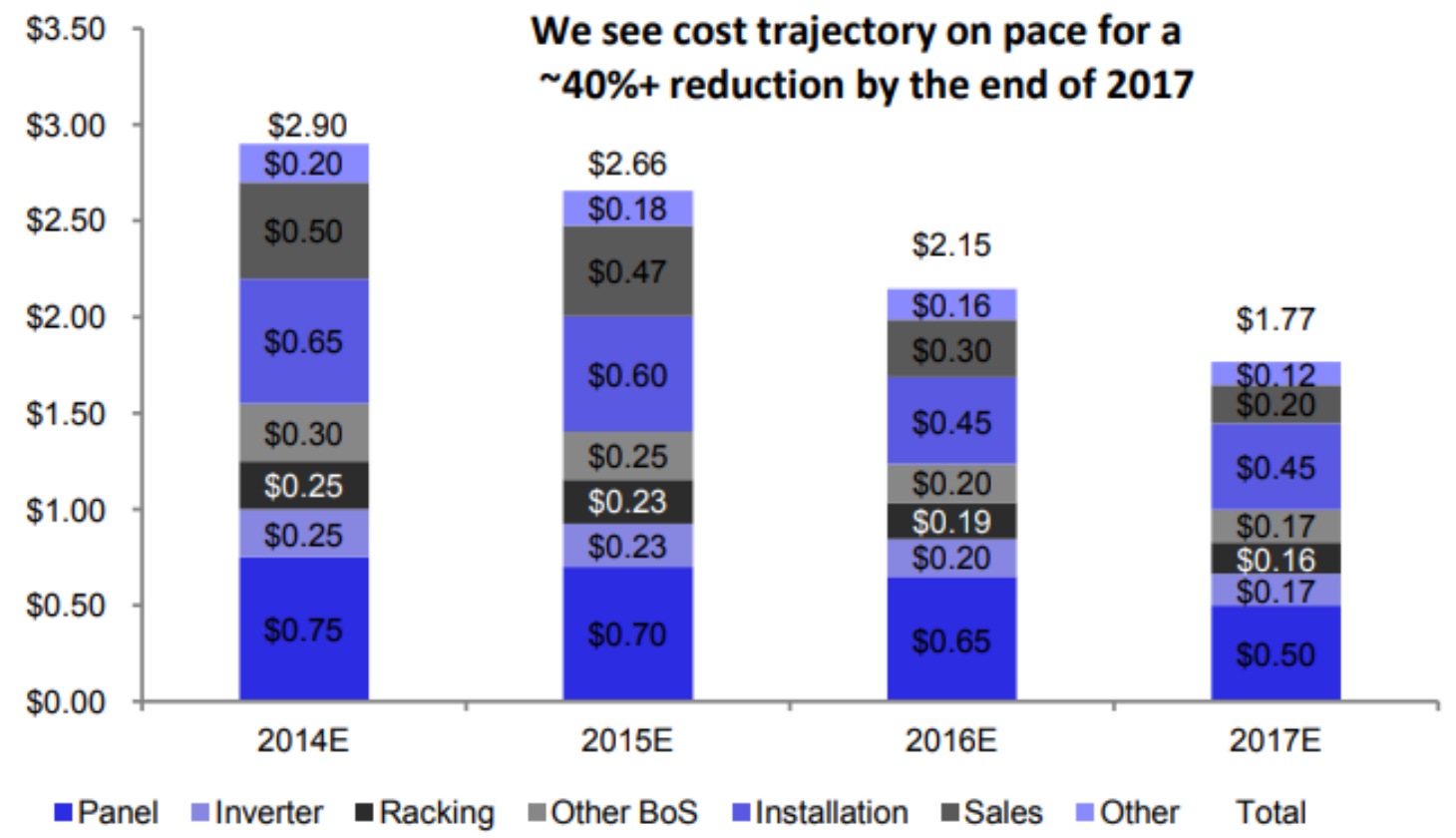

Fig. 1. Cost reduction per watt, Example USA

Another characteristic to take into account in any design aimed at the production of photovoltaic solar energy, is the solar irradiation that exists in the geographical location where the system is intended to be implemented [7] [8]. Depending on the location there can be a greater or lesser strength of sun and therefore can have a greater solar irradiation. In the case of Colombia, it is necessary to take as a reference the information provided by the IDEAM (Institute of Hydrology, Meteorology and Environmental Studies) governmental institution in charge of providing the reference information in the country. For the case study, the Radiation Atlas incorporates solar, ultraviolet and ozone of Colombia [9] and thus have a starting point of the potential energy potential of the area and point of comparison.

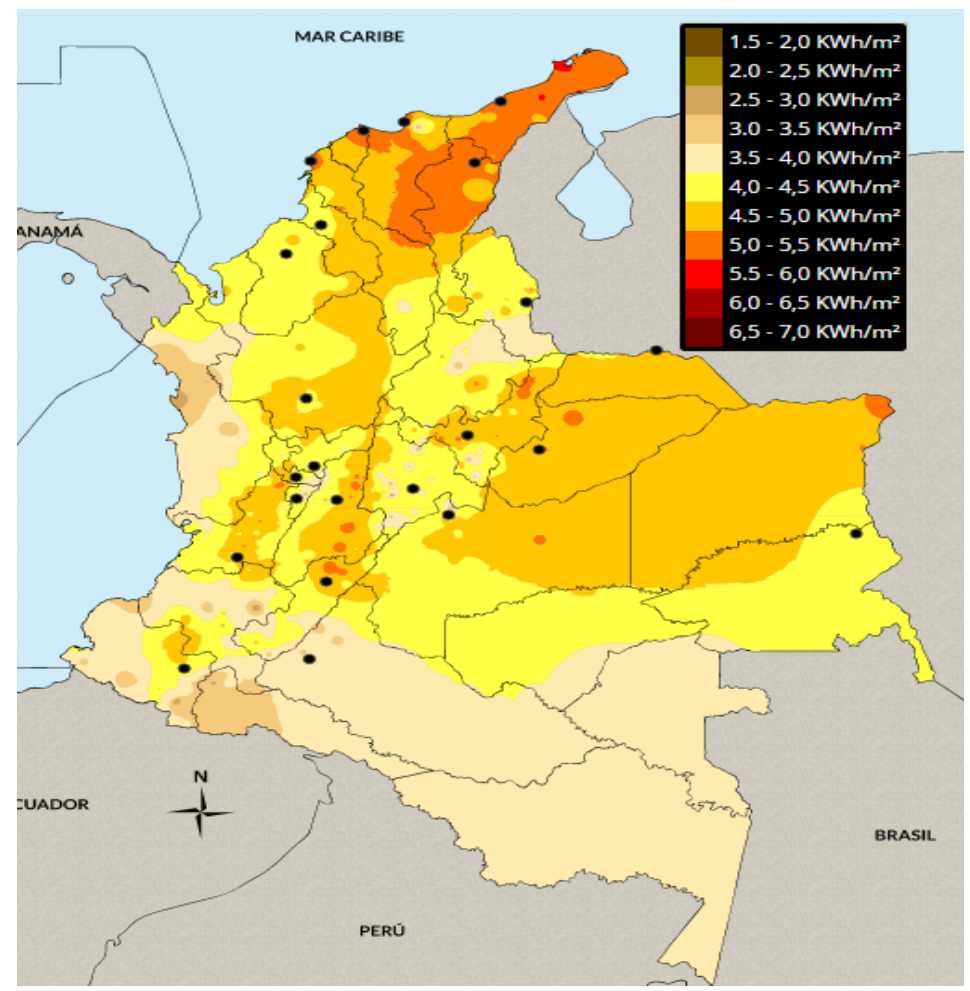

Fig. 2. Atlas of solar radiation, ultraviolet and ozone of Colombia 
The solar map in Colombia provided by the IDEAM, shows different measurements in each of its departments which present the global average daily horizontal irradiation measurements of $1.5 \mathrm{KWh} / \mathrm{m}^{2}$ up to $6.0 \mathrm{kWh} \mathrm{/} \mathrm{m}^{2}$ therefore making some departments and / or municipalities potentially feasible for the implementation of energy production systems based on solar panels. For example, the municipality of Acacias, which has a global average daily irradiation of $4.5-5.0 \mathrm{KWh} / \mathrm{m}^{2}$, making the municipality of Acacias a potential location for production of photovoltaic solar energy [9].

\section{DESCRIPTION OF THE SENSORS FOR MEASUREMENT}

The sensor implemented for the measurement of solar irradiated power is based on two solar panels of $10 \mathrm{~W}$. Each of them has a maximum voltage of $17.4 \mathrm{~V}$ and a maximum current of $0.58 \mathrm{~A}$, which are installed separately. The first in a Fixed position with an inclination of 30 degrees horizontal and pointing directly towards the East. The second is based on a system of active solar tracking of an axis [10] that follows the trajectory of the sun during the day.

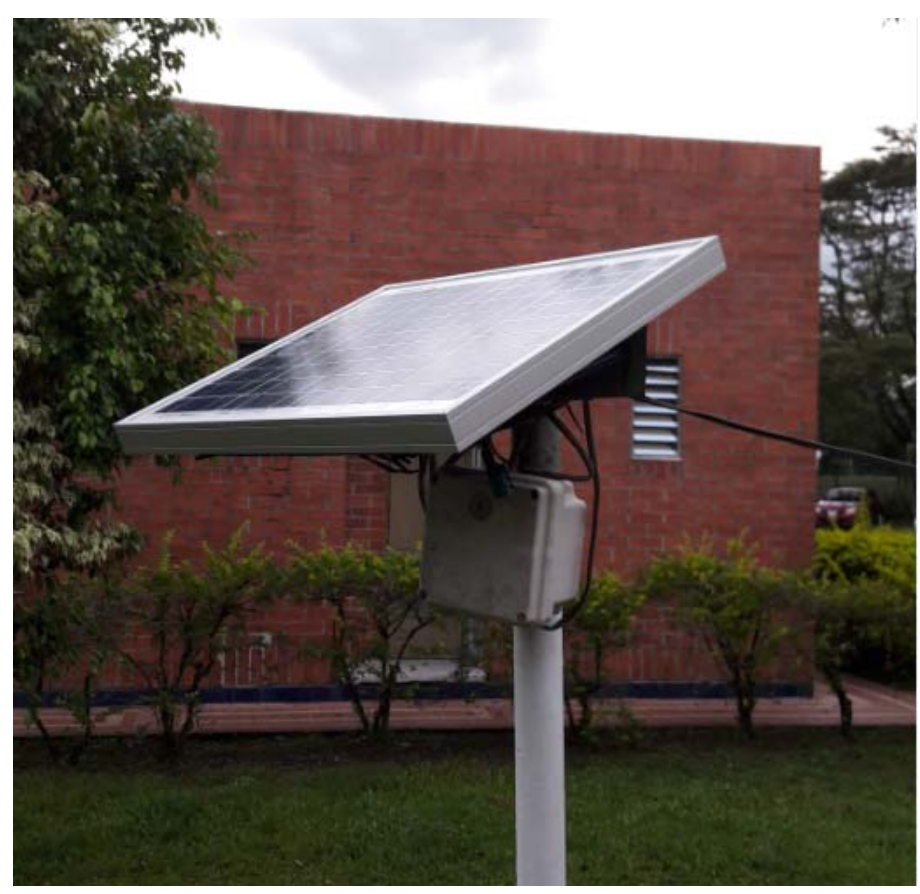

Fig. 3. Fixed solar panel

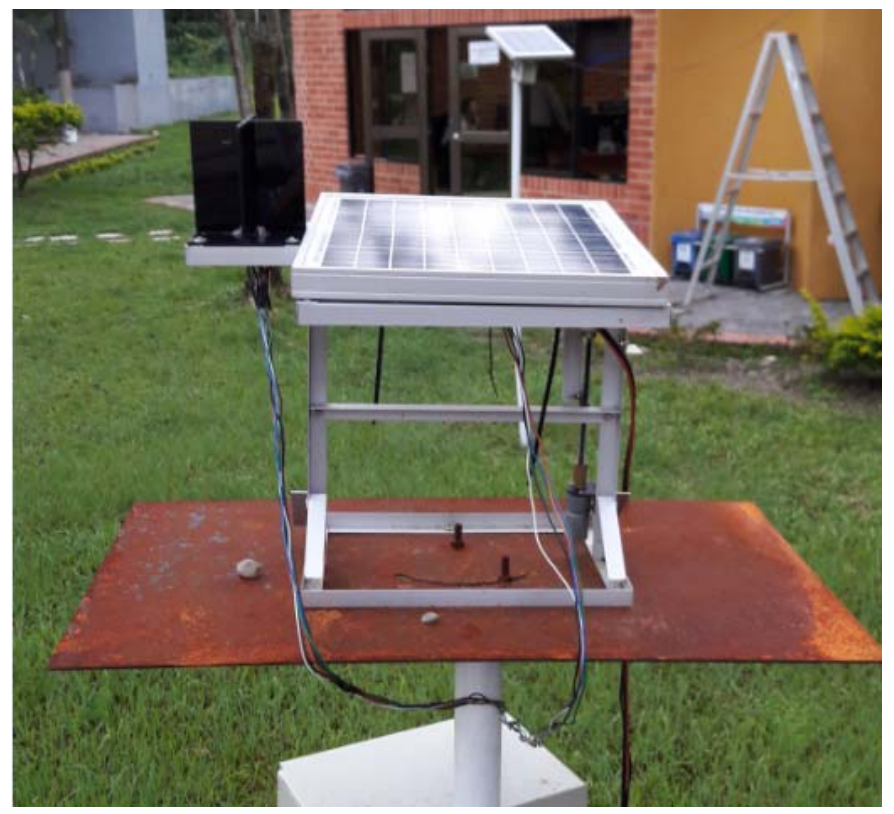

Fig. 4. One axis active solar tracking system 


\section{SOLAR STORAGE AND TRACKING SYSTEM}

The solar tracking system is built by light-sensitive resistances (Photocells) in which the variation of the measurement of its resistive value in Ohms [11] is measured in order to find the position of the sun. The resistive changes are measured by means of a voltage divider and are processed by an Arduino Mega Card. This in turn sends the electrical signals to a $\mathrm{H}$ bridge that controls a motor with a linear effector to perform the movement of the solar panel. The system solar tracking has the ability to change the inclination to a range of 140 degrees. On the other hand, the system captures the solar power every 10 minutes and stores the date readings, time and solar power on a micro SD card to later perform the analysis of the data [12]. The system of the fixed solar panel has the same configuration for the measurement and storage of the power, but it lacks a solar tracking system.

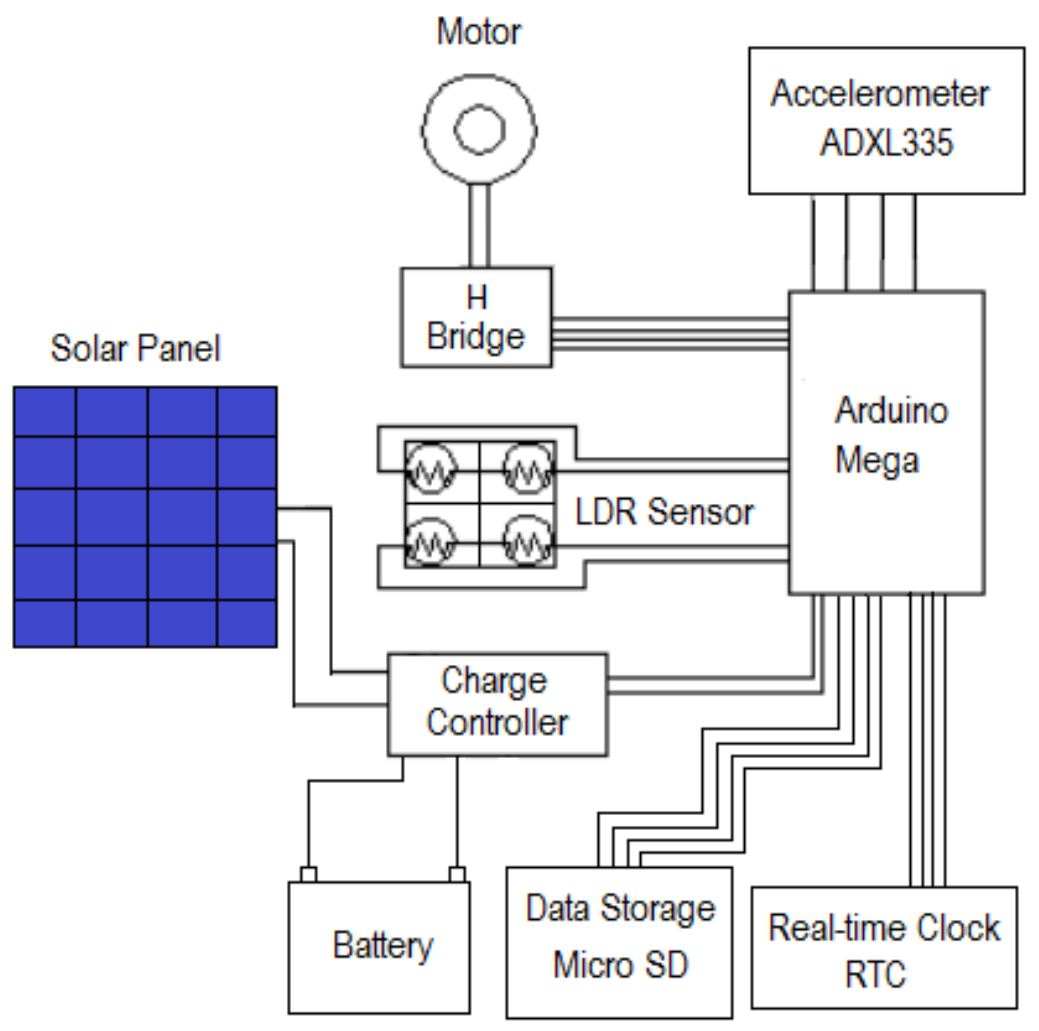

Fig. 5. Solar tracking system and solar power capture

\section{DETERMINGING THE LOCATION OF THE SOLAR PANELS}

To have a good location for solar panels and obtain good results in the measurement of solar power for both types (fixed-system and solar tracking system), it was necessary to take into account the buildings of the University and the trees near where the panels would be located. This is in order to not have a latent shadow at any time of the day or any time of the year due to the phenomenon that arises from the summer and winter solstice [13] caused by the movement of the earth around the sun. In order to make the ideal location, we worked with the online tool SunEarthTools [14], which shows the sun's rays and shadow rays that are projected over any geographical location at any time of the day. It also shows the exact location of the sun with respect to the east at any time of the year. This tool is supported by Google Maps to establish the location and draw the rays on the map, and can determine the optimal location within the facilities of the University. 


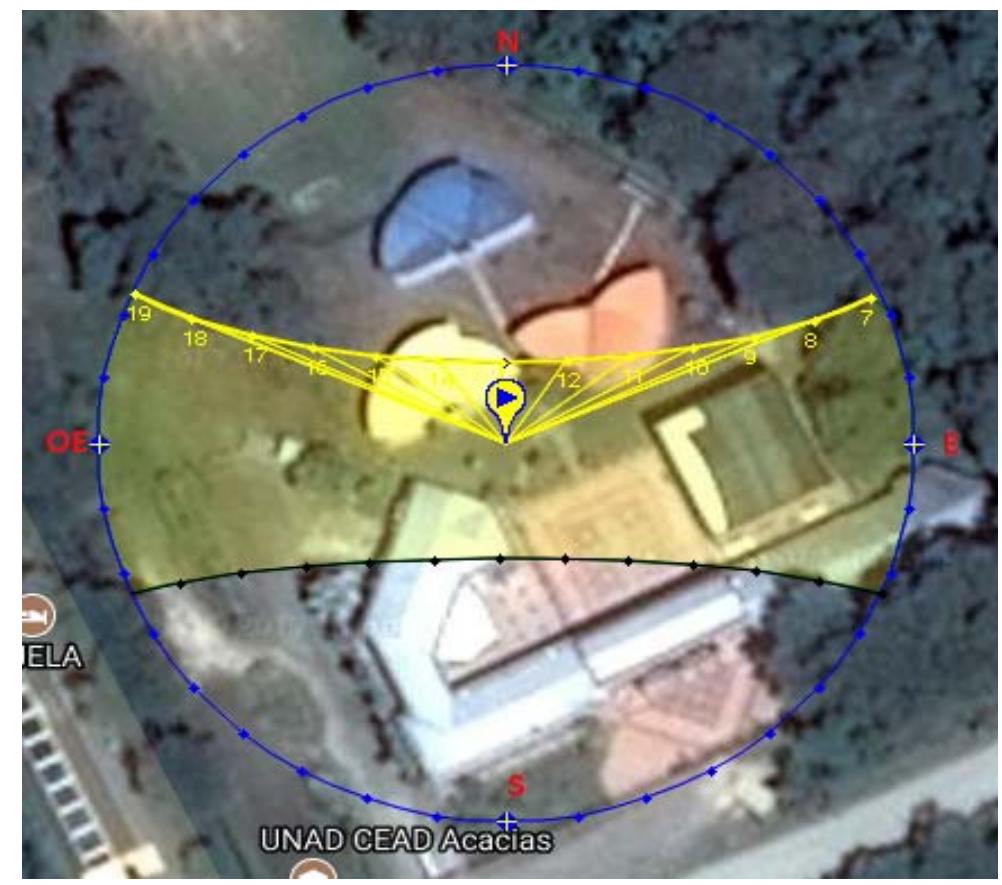

Fig. 6. Location of solar panels

Measurement time

\section{ANALYSIS OF RESULTS}

The solar power measurement system began in July 2016 and was completed in June 2017. There was a 12month information window and after making measurements in 10-minute intervals, a total of 10025 records were obtained with information on the power of the fixed solar panel and the solar tracking system. This provided the database for the study of the horizontal solar irradiation of the area.

Average horizontal solar irradiation

The average horizontal solar irradiation [15], allowed us to establish the average solar power per hour from $6 \mathrm{am}$ to $5 \mathrm{pm}$ for both solar panels. This determines the irradiation values in a panel of $10 \mathrm{~W}$ and resizes the areas to obtain the average power for each $\mathrm{m}^{2}$.

TABLE 1. Horizontal solar irradiation per day

\begin{tabular}{|c|c|c|}
\cline { 2 - 3 } \multicolumn{1}{c|}{} & Stactic Solar Panel & Mobile Solar panel \\
\hline Hour & Power $m^{2}(W)$ & ${\text { Power } m^{2}(W)}^{c}(\mathrm{~W})$ \\
\hline 6:00 AM & 1.5 & 10.2 \\
\hline 7:00 AM & 8.2 & 42.5 \\
\hline 8:00 AM & 28.1 & 60.6 \\
\hline 9:00 AM & 46.8 & 64.9 \\
\hline 10:00 AM & 59.3 & 60.5 \\
\hline 11:00 AM & 63.4 & 66.0 \\
\hline 12:00 PM & 60.4 & 64.6 \\
\hline 1:00 PM & 45.1 & 59.0 \\
\hline 2:00 PM & 20.0 & 59.4 \\
\hline 3:00 PM & 8.4 & 51.5 \\
\hline 4:00 PM & 1.7 & 10.2 \\
\hline 5:00 PM & 0.6 & 3.6 \\
\hline Total/day & 343.5 & 553.0 \\
\hline
\end{tabular}


The data obtained with the fixed solar panel and the solar tracking system showed considerable differences in the production of average electrical power per day. The fixed solar panel system produces a power greater than $70 \%$ of the effective power per $\mathrm{m}^{2}$ from $10: 00$ am to $1: 00 \mathrm{pm}$, about 3 hours per day, while the solar panel system with solar tracking produces a power greater than $70 \%$ of the effective power per $\mathrm{m}^{2}$ from 8:00 a.m. to 2 p.m, about 6 hours per day. This equates to an additional 3 hours of energy production per day, with a power greater than $70 \%$ of the effective power of the area.

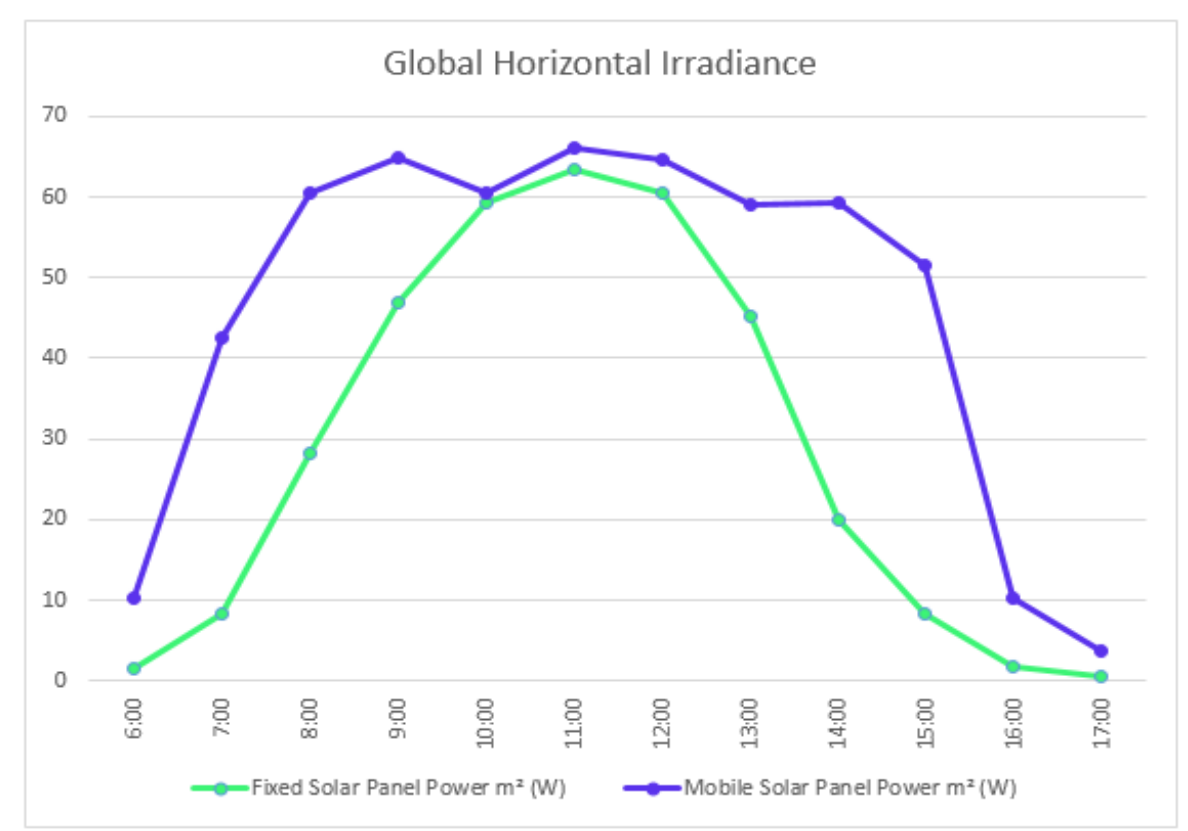

Fig. 7. Global Horizontal irradiance average per day in Acacias

Power generated per month

The capture of solar power by the fixed solar panel type totals $314.9 \mathrm{Kw}$ in the period analyzed, while the solar panel system with solar tracking type in the same period was close to $507.2 \mathrm{Kw}$. This reveals a substantial increase in $192.03 \mathrm{Kw}$, equivalent to an additional production of $61.09 \%$ between both systems. Next, the monthly data of the measurements are presented:

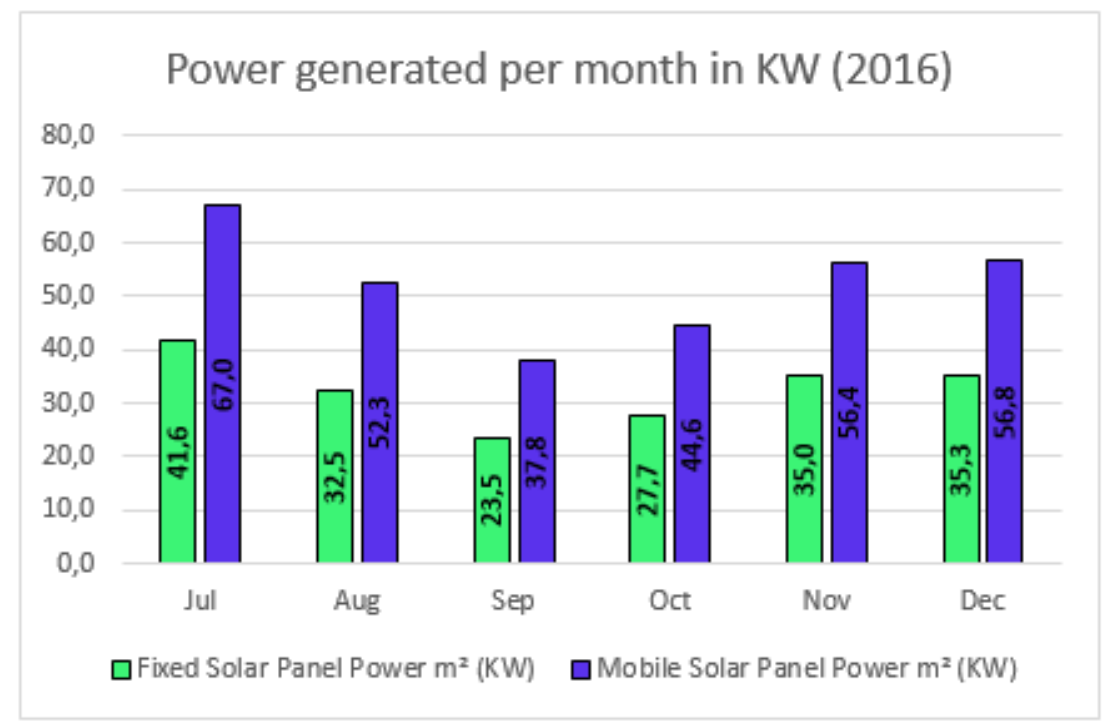

Fig. 8. Power generated per month in KW (2016) 


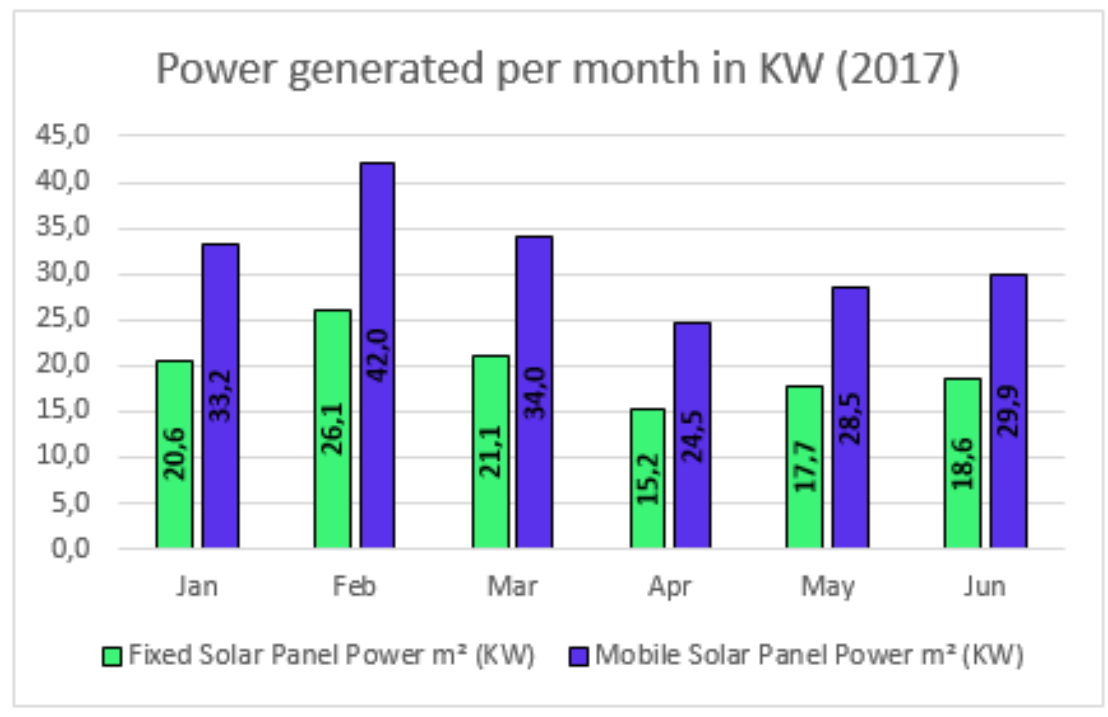

Fig. 9. Power generated per month in KW (2017)

\section{ECONOMIC BENEFITS FOR THE UNIVERSITY}

The energy potential of the area is acceptable so that the university can consider generating electricity from solar photovoltaic energy [16], taking into account that the cost of Kw/h is \$ 0.16 USD. In this case, for the period analyzed, the fixed solar panel system generated $314.9 \mathrm{Kw}$ per $\mathrm{m}^{2}$, equivalent to a cost of \$ $49.67 \mathrm{USD}$, and the solar panel system with solar tracking $507.2 \mathrm{Kw}$ per $\mathrm{m}^{2}$, equivalent to a cost of \$ $80.01 \mathrm{USD}$. This demonstrates a difference between both systems of \$ 30.33 USD, indicating significant savings with the solar panel system with solar tracking. In addition, the cost of implementing a solar system with solar tracking for 500W has an approximate cost of \$ 90 which suggests that the investment can be recovered in 3 years. Taking into account that the useful life of a solar panel is 10 to 20 years [17] [18] there is a margin of at least 10 years to produce additional energy compared to a fixed solar panel.

Environmental benefits of the generation of photovoltaic electric power

The production of electricity in Colombia has an environmental footprint due to the fact that coal is used in some parts of the country. The UPME (Mining and Energy Planning Unit) of Colombia has made available an application called FECOC to determine the emissions of $\mathrm{KgCO} 2$ / KWh [19] in the country. According to this application, each $\mathrm{KWh}$ produced in the country emits $0.199 \mathrm{KgCO}_{2}$ into the atmosphere. The reduction of $\mathrm{CO}_{2}$ emissions into the atmosphere can be achieved by using the two solar panels presented in this research.

The fixed solar panel generated $314.9 \mathrm{Kw}$ in one year per $\mathrm{m}^{2}$ which is equivalent to a decrease of 62.66 $\mathrm{KgCO}_{2}$ into the atmosphere, while the solar panel system with solar tracking generated $507.2 \mathrm{Kw}$ in one year per $\mathrm{m}^{2}$, equivalent to a decrease of $100.9 \mathrm{KgCO}_{2}$ in emissions. Both types of solar panels would therefore contribute to the mitigation of climate change.

\section{CONCLUSIONS}

Researching and implementing solar tracking systems and solar panels is a great strategy in helping to fulfill the goals of the Paris Conference by Colombia.

The energy estimates for the tracking system are very high, since it is approximately $61 \%$ compared to the site measurements of the static system. However, as there only a year of continuous measurements, it is necessary to carry out a larger number of measurements, to make comparisons between months with the purpose of knowing the possible variations year after year.

The implementation of solar tracking systems and online energy production backed by research, prove to be self-sustaining economically. This is considering the time of use of a solar panel versus the time of investment return made in the system, which is little less than 3 years. It is a fairly high and optimal investment compared with other types of businesses in energy.

In the department of Meta, Colombia, the use of solar energy systems is very limited. The use of solar trackers for the production of electrical energy in similar studies have different possibilities for business development and offer preliminary work in the analysis and energy characterization of the region. It allows bodies such as IDEAM, UPME and others to contrast their resources and verify the changes in solar calculations in the region. 


\section{REFERENCES}

[1] M. Moniruzzaman y S. Hasan, «Cost analysis of PV/Wind/diesel/grid connected hybrid systems,» de 2012 International Conference on Informatics, Electronics \& Vision (ICIEV), Dhaka, 2012.

[2] C. Kerebel y D. Stoerring, «La energia renovable,» 14 December $2016 . \quad$ [On Line]. Available: http://www.europarl.europa.eu/atyourservice/es/displayFtu.html?ftuId=FTU_5.7.4.html. [Last access: 02 June 2017].

[3] European Commission, «European Commission,» European Commission, February 2016. [On Line]. Available: https://ec.europa.eu/clima/policies/international/negotiations/paris_es. [Last access: 24 November 2017].

[4] Publicaciones Semana S.A., «El impuesto al carbono evitará costos ambientales y riesgos sobre la salud humana,» Publicaciones Semana S.A., 4 january 2017. [On Line]. Available: http://sostenibilidad.semana.com/impacto/articulo/el-ministro-luis-gilbertomurillo-explica-el-impuesto-al-carbono/36787. [Last access: 24 November 2017].

[5] I. Moussa, A. Bouallegue y A. Khedher, «Development of a low cost PV simulator based on FPGA technology,» of 2017 International Conference on Green Energy Conversion Systems (GECS), Hammamet, 2017.

[6] Deutsche Bank, «Qualenergia,» 27 February 2015. [On Line]. Available: http://www.qualenergia.it/sites/default/files/articolodoc/Solar\%20FITT.pdf. [Last access: 24 Noviembre 24].

[7] K. Shruthi, C. Viswanatha, K. Giridhar y M. Divekar, «Anomalies in practical solar photovoltaic installations and tilt angle optimization,» of 2016 IEEE International Conference on Power Electronics, Drives and Energy Systems (PEDES), Trivandrum, 2016.

[8] L. Jiang, D. Maskell, R. Srivatsan y Q. Xu, «Power variability of small scale PV systems caused by shading from passing clouds in tropical region,» de 2016 IEEE 43rd Photovoltaic Specialists Conference (PVSC), Portland, 2016.

[9] IDEAM, «Atlas de radiación solar, ultravioleta y ozono de Colombia,» June 2014. [On Line]. Available: http://atlas.ideam.gov.co/visorAtlasRadiacion.html. [Last access: 2 junio 2017].

[10] E. Kabalci, A. Calpbinici y Y. Kabalci, «A Single-Axis Solar Tracking System and Monitoring Software,» de 015 7th International Conference on Electronics, Computers and Artificial Intelligence (ECAI), Bucharest, 2015.

[11] J. I. Gabe, A. Buhler, D. Chesini y F. Frosi, «Design and Implementation of a Low-Cost Dual-Axes Autonomous Solar Tracker,» of International Symposium on Power Electronics for Distributed Generation Systems (PEDG), Florianopolis, 2017.

[12] A. Rodriguez y J. Figueredo, «Selección e implementación de un prototipo de estación meteorológica,» de Desarrollo e Innovación en Ingeniería, Medellin, Instituto Antioqueño de Investigación, 2016, pp. 341-352.

[13] G. Dousoky, A.-H. EL-Sayed y M. Shoyama, «Maximizing Energy-Efficiency in Single-Axis Solar Trackers for Photovoltaic Panels,» de 8th International Conference on Power Electronics - ECCE Asia, Jeju, 2011.

[14] SunEarthTools, «SunEarthTools,» 2009. [On Line]. Available: https://www.sunearthtools.com/index.php. [Last access: 05 may 2016 ]

[15] K. Yong, A. Nobre, R. Malhotra, Y. Dazhi, R. Ruther, T. Reindl y A. Aberle, «Optimal Orientation and Tilt Angle for Maximizing inPlane Solar Irradiation for PV Applications in Singapore,» IEEE Journal of Photovoltaics, vol. 4, nº 2, pp. 647-653, 2014.

[16] R. Pacheco-Torres, M. Lopez-Alonso y G. Martinez, «Efficient design of residential buildings geometry to optimize photovoltaic energy generation and energy demand in a warm Mediterranean climate,» ENERGY EFFICIENCY, vol. 8, nº 1, pp. 65-84, 2015.

[17] Z. Bo, Z. Xuesong, L. Peng y Peng, «Optimal sizing, operating strategy and operational experience of a stand-alone microgrid on Dongfushan Island,» APPLIED ENERGY, vol. 113, nº 2, pp. 1656-1666, 2014.

[18] D. Akinyele, R. Rayudu y N. Nair, «Global progress in photovoltaic technologies and the scenario of development of solar panel plant and module performance estimation - Application in Nigeria,» RENEWABLE \& SUSTAINABLE ENERGY REVIEWS, vol. 48, $\mathrm{n}^{\circ}$ 1, pp. 112-139, 2015.

[19] UPME,

«UPME,» $\quad 25 \quad$ February $2016 . \quad$ [On $\quad$ Line] http://www.upme.gov.co/calculadora_emisiones/aplicacion/calculadora.html. [Last access: 27 November 2017].

[20] G. Parkinson, «Clean Technica,» 29 January 2015. [On Line]. Available: https://cleantechnica.com/2015/01/29/solar-costs-will-fall40-next-2-years-heres/. [Last access: 01 June 2017].

[21] A. Rodríguez y A. Chica, «Diseño e implementación de un seguidor solar.» Revista Cap\&Cua, 2011, vol. 6, no 1, p. 3-4. 